Article

\title{
Evaluation of the Antibacterial Effects and Mechanism of Action of Protocatechualdehyde against Ralstonia solanacearum
}

\author{
Shili Li, Yanmei Yu, Juanni Chen, Bing Guo, Liang Yang and Wei Ding * \\ Laboratory of Natural Products Pesticides, College of Plant Protection, Southwest University, Chongqing 400715, \\ China; 1sl2031st@163.com (S.L.); trcmei@126.com (Y.Y.); chenhuanni521@126.com (J.C.); \\ guobing425@163.com (B.G.); ylwzling@163.com (L.Y.) \\ * Correspondence: dingw@swu.edu.cn; Tel./Fax: +86-23-6825-0953
}

Academic Editor: Derek J. McPhee

Received: 1 May 2016; Accepted: 7 June 2016; Published: 9 June 2016

\begin{abstract}
Protocatechualdehyde (PCA) is an important plant-derived natural product that has been associated with a wide variety of biological activities and has been widely used in medicine as an antioxidant, anti-aging and an anti-inflammatory agent. However, fewer reports concerning its antibacterial effects on plant-pathogenic bacteria exist. Therefore, in this study, protocatechualdehyde was evaluated for its antibacterial activity against plant pathogens along with the mechanism of its antibacterial action. PCA at $40 \mu \mathrm{g} / \mathrm{mL}$ was highly active against $R$. solanacearum and significantly inhibited its growth. The minimum bactericidal concentration and minimum inhibitory concentration values for PCA were $40 \mu \mathrm{g} / \mathrm{mL}$ and $20 \mu \mathrm{g} / \mathrm{mL}$, respectively. Further investigation of the mechanism of action of PCA via transmission electron microscopy and biological assays indicated that the destruction of the cell structure, the shapes and the inhibition of biofilm formation were important. In addition, the application of PCA effectively reduced the incidence of bacterial wilt on tobacco under greenhouse conditions, and the control efficiency was as high as $92.01 \%$ at nine days after inoculation. Taken together, these findings suggest that PCA exhibits strong antibacterial activity against $R$. solanacearum and has the potential to be applied as an effective antibacterial agent for controlling bacterial wilt caused by $R$. solanacearum.
\end{abstract}

Keywords: Ralstonia solanacearum; protocatechualdehyde; antibacterial activity; biofilm formation; bacterial wilt

\section{Introduction}

Ralstonia solanacearum is a rod-shaped Gram-negative plant-pathogenic bacterium that causes bacterial wilt disease [1-3]. This soil-borne bacterium can infect more than 200 plant species, mainly in the Solanaceae and Musaceae families [4]. This soil-borne pathogen can also cause typical wilting symptoms by colonization, invasion, survival and growth in the root system and xylem tissue via wounds or natural openings $[5,6]$. During the development of disease, $R$. solanacearum cells secrete several virulence factors, including an extracellular polysaccharide, several plant cell wall-degrading enzymes and some type III-secreted effectors [7-11]. The pathogen is widely distributed in tropical, subtropical and some temperate regions and affects significant economic crops, such as tomato, banana, potato, and tobacco. The bacterium can be free-living in soil or in water as a saprophyte after destroying the host [12]. Therefore, $R$. solanacearum is one of the most destructive pathogens of many economically important plants [3].

To control bacterial wilt, agrochemicals, such as copper derivatives, antibiotics and quaternary ammonium compounds, are conventionally used for crop protection [13,14]. However, the application of these traditional agrochemicals has been proven not very effective in controlling this soil-borne 
bacterium. At the same time, the overuse of bactericides can cause severe side effects, especially the production of resistant strains and environmental pollution $[15,16]$. Agricultural controls, including resistant cultivars, tillage management, pathogen-free transplants and crop rotation are widely used in prevention research. However, because R. solanacearum can remain in the soil for a long time outside of the host plant, few efforts involving agricultural management have been made to control $R$. solanacearum once a bacterial wilt outbreak has occurred $[17,18]$. Thus, there is an immediate need for the development of a new alternative agent or potent anti-R. solanacearum compounds to effectively control this bacterium.

Botanical substances contain abundant bactericidally active materials, and these materials have activity against a broad spectrum of bacteria, are easily decomposed, are unlikely to pollute the environment, have no significant toxicity to vertebrates and the host plant, and have a low cost of renewal and other advantages [4,19]. Several studies have demonstrated that the use of botanical compounds to prevent $R$. solanacearum infection may be effective. Methyl gallate (MG) from Toxicodendron sylvestre was shown to significantly inhibit $R$. solanacearum growth in vitro and in planta $[20,21]$, and it was shown to be able to damage the cell wall structure, inhibit protein synthesis and succinate dehydrogenase (SDH) activity in the pathogen [22]. Similarly, the antibacterial activity of Lansiumamide B on R. solanacearum and its control efficiency in potting medium were evaluated by in vitro assays [4]. Earlier experiments demonstrated that thymol, palmarosa, lemongrass, and eucalyptus oils could reduce $R$. solanacearum populations in heavily infested potting medium $[23,24]$ by inducing changes in the cell structure at the sub-cellular level and caused a significant reduction of many physiological metabolites [25]. Others substances, including active components of gallnuts [26], essential oils of cinnamon, thyme, lavender, eucalyptus [14], and an Allium fistulosum extract [27], have been reported to have antibacterial activity against $R$. solanacearum. However, most current research is focused on botanical compounds for the control of $R$. solanacearum in in vitro assays or in potted plants, and few plant compounds have been used to control plant bacterial wilt in planta until now. The use of botanically active materials for the development of new, environmentally friendly pesticides will become an inevitable trend [28].

Protocatechualdehyde (protocatechnic aldehyde, PCA) is a natural polyphenol compound that is isolated from the roots of traditional Chinese medicine radix Salviae Miltiorrhizae [29,30], and previous studies have shown that PCA has pharmacological properties, including antioxidant, cardiovascular and anti-inflammatory activities [31]. Although PCA has been reported to have broad antibacterial anti-inflammatory effects, its antibacterial activity has not been documented. Therefore, in this study, we evaluated the antibacterial potential of PCA against soil-borne pathogens in vitro and in vivo, as well as its mechanism of action.

\section{Results}

2.1. The Minimum Inhibitory Concentration and Minimum Bactericidal Concentration Values of PCA on R. solanacearum

The minimum inhibitory concentration (MIC) and minimum bactericidal concentration (MBC) of PCA against $R$. solanacearum were measured by using the serial two-fold agar dilution method. The MIC and MBC value against $R$. solanacearum were $20 \mu \mathrm{g} / \mathrm{mL}$ and $40 \mu \mathrm{g} / \mathrm{mL}$, respectively. It was able to completely inhibit $R$. solanacearum at a concentrations of $40 \mu \mathrm{g} / \mathrm{mL}$ on agar media (Figure 1). However, the solvent dimethylsulfoxide (DMSO) had no effect on the growth of $R$. solanacearum on plates at $48 \mathrm{~h}$ and $96 \mathrm{~h}$. 

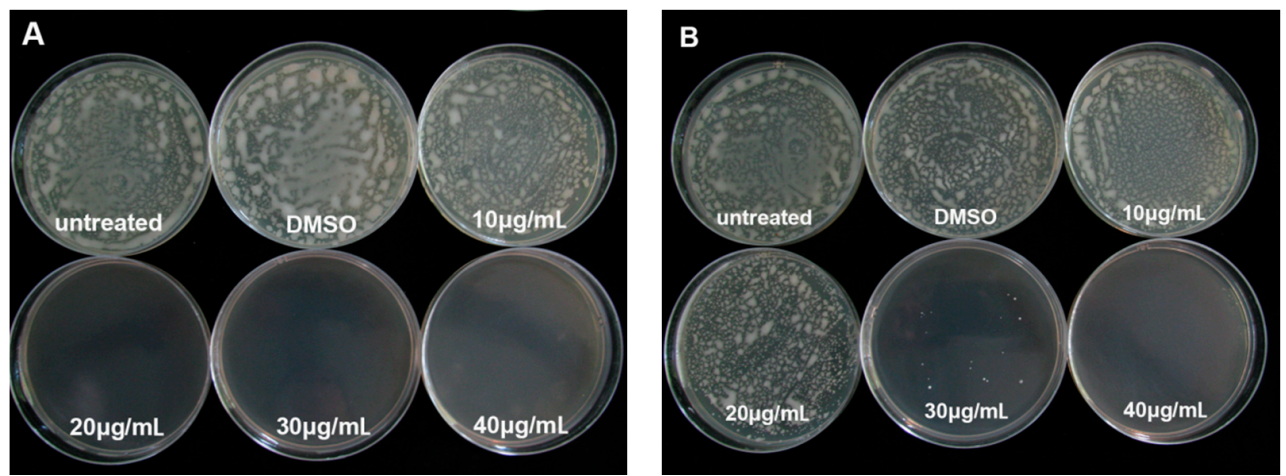

Figure 1. Effect of PCA on the growth of R. solanacearum after cultured for $48 \mathrm{~h}(\mathbf{A})$ and $96 \mathrm{~h}(\mathbf{B})$.

\subsection{R. solanacearum Growth Curves with PCA Treatment}

In this study, the antibacterial activity of PCA was estimated by growth curves using the turbidimeter test method. The cells were treated with PCA concentrations of 10, 20, 30 and $40 \mu \mathrm{g} / \mathrm{mL}$, and PCA significantly inhibited the growth of the bacteria at 30 and $40 \mu \mathrm{g} / \mathrm{mL}$ treatment; a PCA concentration of $40 \mu \mathrm{g} / \mathrm{mL}$ almost completely stopped $R$. solanacearum growth after $26 \mathrm{~h}$ incubation (Figure 2).

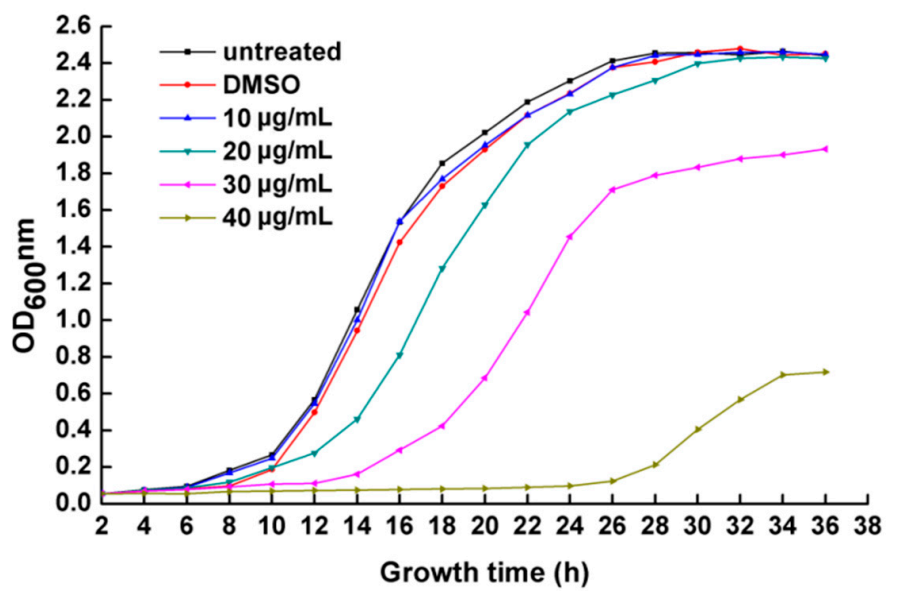

Figure 2. OD growth curves of $R$. solanacearum in the presence of different PCA concentrations at $30{ }^{\circ} \mathrm{C}$. Untreated bacteria were treated with sterile water. Bacteria were also treated with DMSO alone at a final concentration of $0.1 \%$. The OD value of each treatment was the average of three replicates.

\subsection{Morphology Characterization of R. solanacearum by SEM}

SEM images of the morphology of $R$. solanacearum after inoculation with PCA concentrations of 30 and $40 \mu \mathrm{g} / \mathrm{mL}$ were taken. Under our experimental conditions, the untreated bacteria (Figure 3A) and $0.1 \%$ DMSO-treated (Figure 3B) bacteria showed typical $R$. solanacearum morphology-a short rod shape with the integrity of the membrane structure intact and a smooth texture; moreover, no significant difference between these treatments was evident. In contrast, PCA treatment at both concentrations obviously destroyed the surface structure of the bacterial cells and shapes (Figure 3C,D and Figure 4). The shape of the treated cells was longer than the untreated cells and their cellular integrity was lost at a concentration of 30 and $40 \mu \mathrm{g} / \mathrm{mL}$ (Figures $3 \mathrm{C}$ and 4). Additionally, the widths of treated cells were significantly decreased compared to the control groups (Figure 4). In addition, the cells treated with $40 \mu \mathrm{g} / \mathrm{mL}$ PCA showed greater damage than those treated with $30 \mu \mathrm{g} / \mathrm{mL}$ PCA (Figures 3D and 4). These results suggested that PCA could damage the cell wall of $R$. solanacearum and that the damaging effect was greater at a higher concentration. 

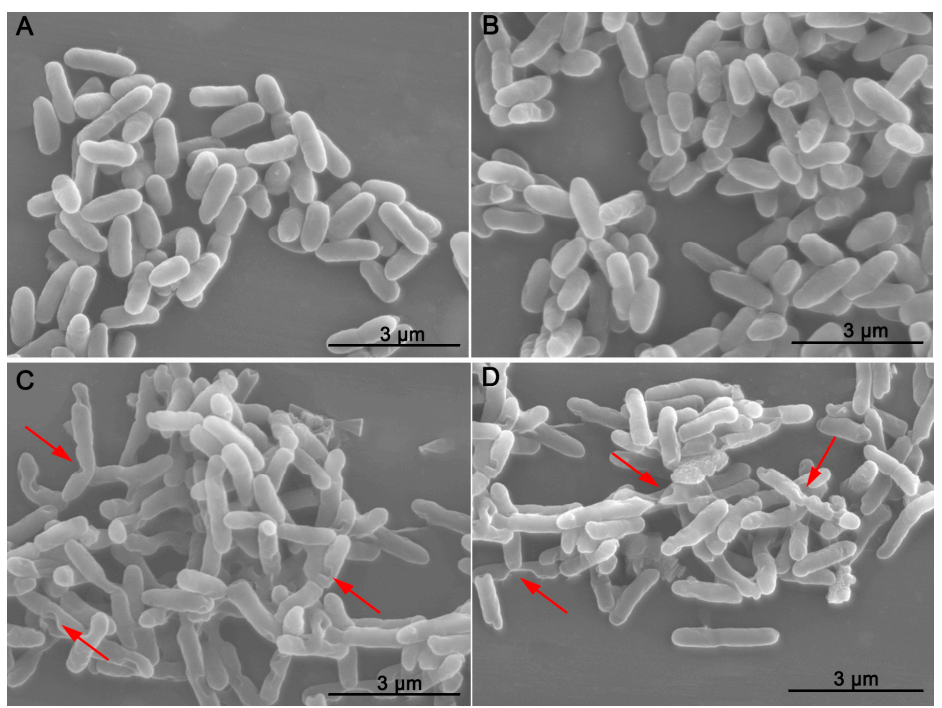

Figure 3. SEM images of $R$. solanacearum cells treated with PCA at different concentrations. (A) Untreated cells; (B) Cells treated with DMSO alone at a final concentration of 1\%; (C) Cells treated with $30 \mu \mathrm{g} / \mathrm{mL}$ PCA; (D) Cells treated with $40 \mu \mathrm{g} / \mathrm{mL}$ PCA. Cells were incubated for $12 \mathrm{~h}$ with shaking at $180 \mathrm{rpm}$ at $30^{\circ} \mathrm{C}$.

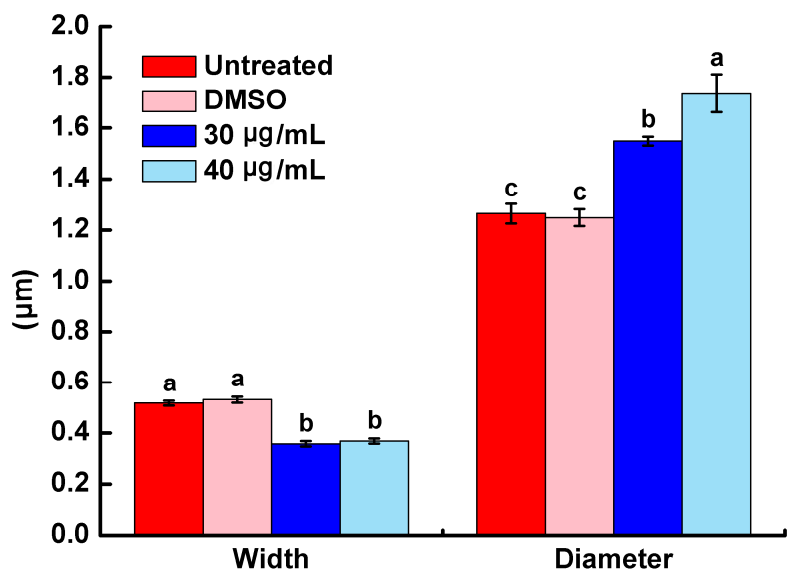

Figure 4. Effects of different treatments on width and diameter of $R$. solanacearum cells. The mean value of width and diameter was calculated based on scale bars of SEM images. The error bars indicate the standard error of the mean from 100 cells. Lower case letters indicate significant differences according to Duncan's test $(p<0.05)$.

\subsection{Effect of PCA on Biofilm Formation in R. solanacearum}

After treatment with PCA concentrations of 10, 20, 30 and $40 \mu \mathrm{g} / \mathrm{mL}$, the biofilm formation of $R$. solanacearum was determined after 12, 24 and $36 \mathrm{~h}$. The biomass in all treatments increased with time from $12 \mathrm{~h}$ to $36 \mathrm{~h}$ (Figure 5). Biofilm formation was significantly greater in the control and DMSO (without PCA) groups than in the treatment groups ranging from 0.11 to 0.21 and 0.10 to 0.20 , respectively. Furthermore, the bioactivity of PCA activity was concentration-dependent, and the biofilm formation was gradually suppressed by PCA as the concentrations increased (Figure 5). A low concentration of $10 \mu \mathrm{g} / \mathrm{mL}$ did not inhibit biofilm formation, but 30 and $40 \mu \mathrm{g} / \mathrm{mL}$ were found to notably inhibit biofilm formation. Compared with the control, biofilm formation after the $40 \mu \mathrm{g} / \mathrm{mL}$ treatment significantly reduced biofilm formation by $48.11 \%$ and $38.90 \%$, and by $38.56 \%$ and $37.27 \%$ after the $30 \mu \mathrm{g} / \mathrm{mL}$ treatment, at 24 and $36 \mathrm{~h}$, respectively (Figure 6). The results showed that PCA exhibited a strongly inhibitory on $R$. solanacearum biofilm formation. 


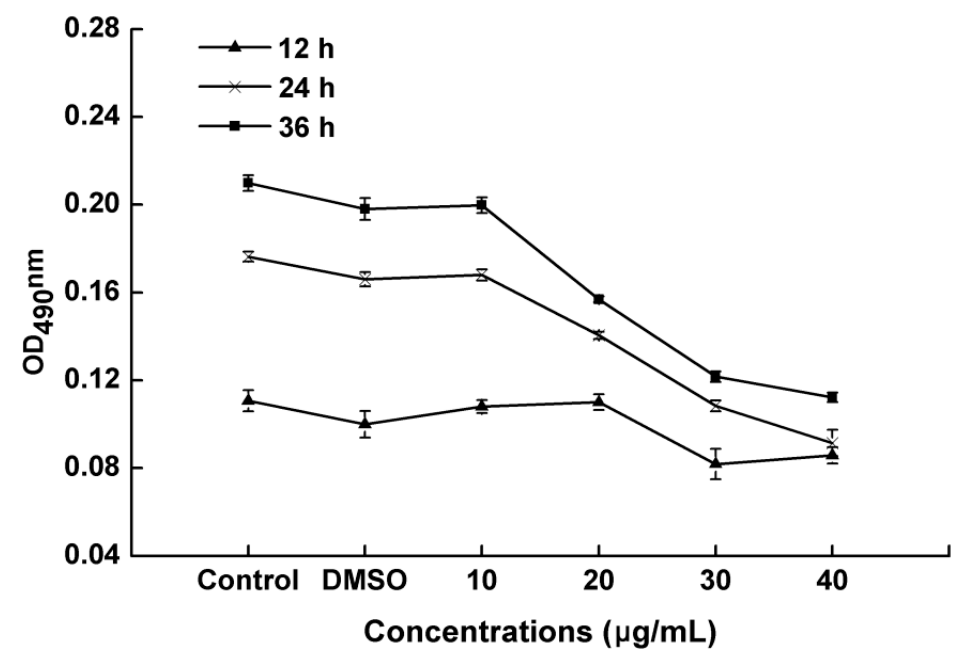

Figure 5. Effects of different concentrations $(10,20,30$ and $40 \mu \mathrm{g} / \mathrm{mL})$ of PCA on biofilm formation in R. solanacearum. Cells were treated with DMSO alone at a final concentration of $1 \%$ (DMSO treatment), sterile water (Untreated) and PCA at a final concentration of 10, 20, 30 and $40 \mu \mathrm{g} / \mathrm{mL}$ (PCA treatments). Experiments were incubated for 12,24 and $36 \mathrm{~h}$ at $30^{\circ} \mathrm{C}$ without shaking.

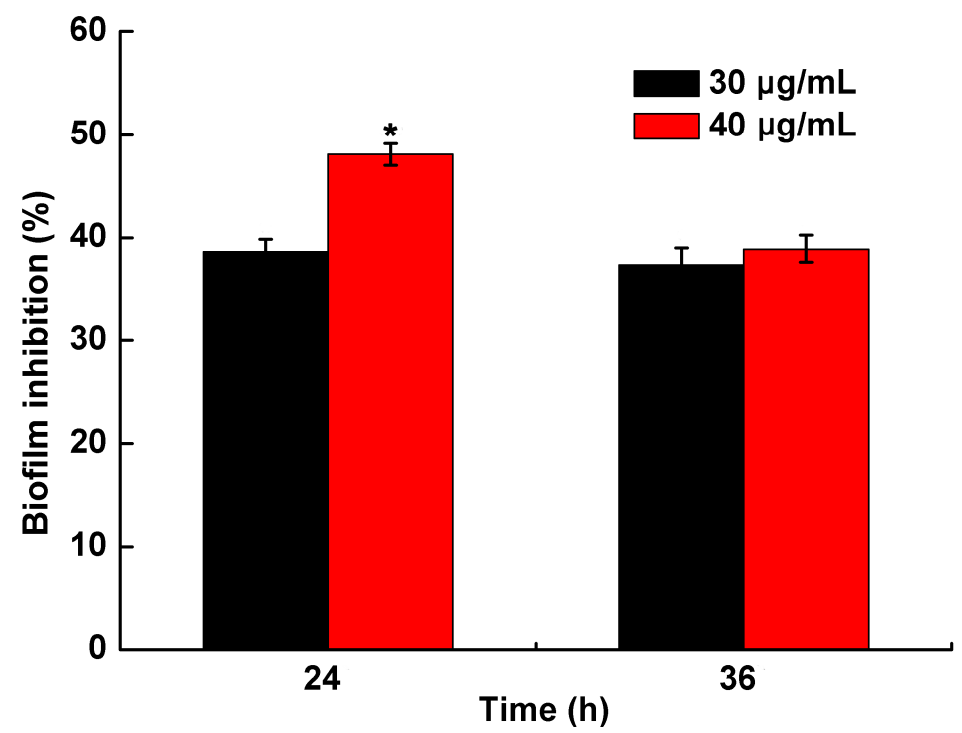

Figure 6. Inhibition effect of PCA on biofilm formation of R. solanacearum. Biofilm inhibition (\%) was quantified after treatment with concentrations of 30 and $40 \mu \mathrm{g} / \mathrm{mL}$ at 24 and $36 \mathrm{~h}$ in the 96 -well plates. The symbol indicate significant differences according to independent-samples $T$ test $\left({ }^{*}\right.$ indicated $p<0.01)$.

\subsection{Assessment of R. solanacearum Swarming Motility in the Presence of PCA}

Motility was considered to be closely and positively related with biofilm formation. The previous experiment demonstrated that PCA could obviously suppress biofilm formation. We investigated whether PCA could affect the motility of $R$. solanacearum in a petri dish. The results indicated that PCA could significantly inhibit swarming motility at concentrations ranging from 10 to $40 \mu \mathrm{g} / \mathrm{mL}$ after 24 and $48 \mathrm{~h}$ (Figure 7). At $24 \mathrm{~h}$, the diameter of the migration zone was decreased by 2.12and 2.07-fold compared with the control. Moreover, the inhibitory effect of PCA on the swarming motility after $48 \mathrm{~h}$ was more evident and the diameter of the migration zone was reduced by 4.08 -fold. This experiment indicated that PCA potently exerted an obvious inhibitory effect on the swarming motility of $R$. solanacearum in a dose-dependent manner. 


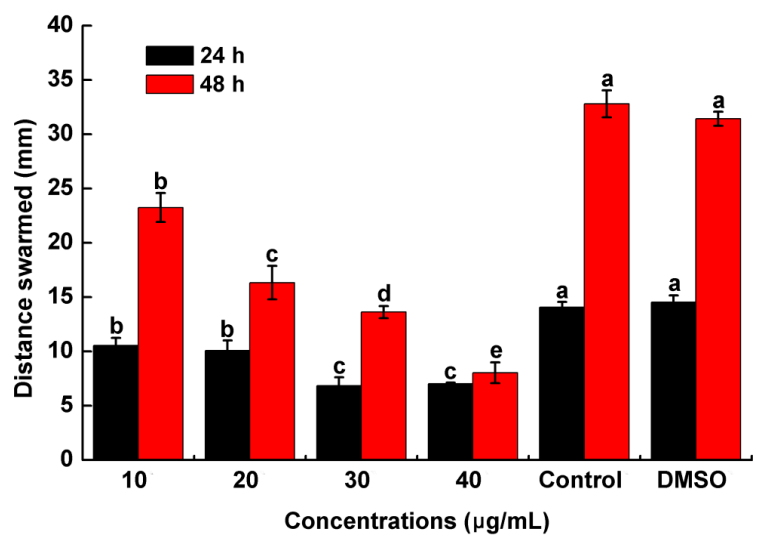

Figure 7. Effects of PCA at different concentrations on R. solanacearum swarming in swarming medium. The swarming diameter was measured in both the vertical and horizontal direction on each plate after incubation for $24 \mathrm{~h}$ and $48 \mathrm{~h}$ at $28^{\circ} \mathrm{C}$. The mean value in both directions was calculated. The diameter represents the average of triplicate plates. The assays were independently repeated three times. The error bars indicate the standard error of the mean from three replicates. Lower case letters indicate significant differences according to Duncan's test $(p<0.05)$.

\subsection{The Pathogenicity of $R$. solanacearum in a Greenhouse Treated with PCA}

PCA at a concentration of $40 \mu \mathrm{g} / \mathrm{mL}$ had the most effective in vitro antibacterial activity, so we selected this concentration for disease assessment in a pot experiment. Beginning at seven days after inoculation, the incidence of disease was assessed every two days from seven to 19 days. Typical bacterial wilt symptoms were observed nine days after the tobacco plants were inoculated with $R$. solanacearum (Figure 8). A significant effect of PCA treatment was shown for the disease index of bacterial wilt. The disease indices of PCA and streptomycin treatments on tobacco bacterial wilt were 18.06 and 51.22 and 48.82 and 78.65, respectively, at 15 and 19 days after inoculation. However, the disease index of the control reached 68.06 and 97.22 at 15 and 19 days, respectively (Figure 8). Moreover, the control efficiency of the PCA and the streptomycin treatments were $92.01 \%$ and $47.31 \%$ and $61.39 \%$ and $19.10 \%$ at nine and 19 days after inoculation (Figure 9), respectively. A concentration of $40 \mu \mathrm{g} / \mathrm{mL}$ of PCA showed extremely significant effects on the control of tobacco bacterial wilt of over $30.62 \%$ and $28.21 \%$ compared to streptomycin at nine and 19 days, respectively.

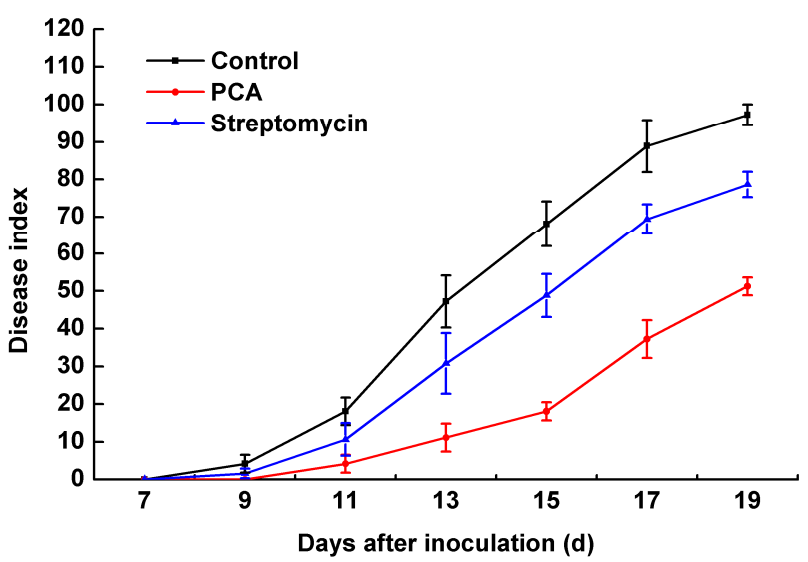

Figure 8. Disease index of bacterial wilt of tobacco with PCA treatment. Unwounded tobacco plants were soil-soak inoculated at concentrations of $5 \mathrm{~mL}\left(1 \times 10^{8} \mathrm{cfu} / \mathrm{mL}\right)$ and inoculated at $28 \pm 1{ }^{\circ} \mathrm{C}$ after treatment with $40 \mu \mathrm{g} / \mathrm{mL}$ PCA. Untreated plants were treated with sterile water. The mean of three replications and the data were from a single representative and reproduced several times. The disease index was expressed as the mean $\pm \mathrm{SE}$. 


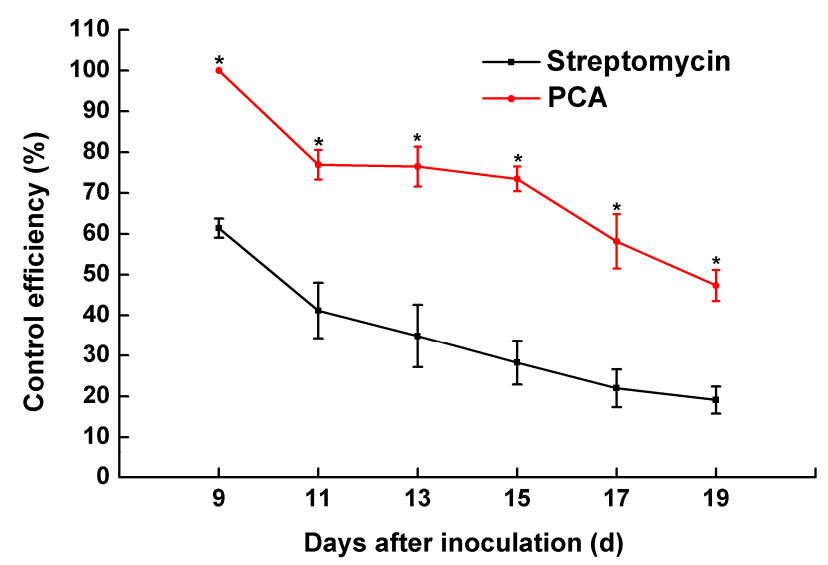

Figure 9. The control effect of PCA on tobacco inoculated with $R$. solanacearum. The bars indicate the standard error of the mean of three replicates. ${ }^{*}$ indicates a significant difference between treatments (independent-samples $T$ test, $p<0.05$ ).

\section{Discussion}

Bacterial wilt of tobacco is a devastating disease worldwide and its threat is constantly increasing. For the last few years, traditional chemosynthesis pesticides have been used to control soil-borne diseases caused by $R$. solanacearum. However, many chemical pesticides pollute the environment and lead to the accumulation of residues in crops and soil. Therefore, in pesticide science, it is essential to search for new natural antibacterial agents that are highly efficient and environmentally friendly [32]. The application of natural products isolated from plants and biological agents has been shown to be effective and environmentally friendly against many plant pathogens [33]. In nature, plants contain a large variety of natural products, many of which have evolved to have antimicrobial activity against pathogens that cause bacterial and fungal diseases, such as flavonoids [34], phenols [35], sesqrepenes [36], alkaloids [37], and coumarins [38]. PCA is a water-soluble antioxidant phenolic aldehyde extracted from the roots of Salvia miltiorrhiza, and it has been widely used in many fields of medicine and biological research $[39,40]$. However, its potential bactericidal activity against soil-borne pathogens has not been intensively investigated. Therefore, in this research, the antibacterial potentials of PCA against $R$. solanacearum and the mechanism of action were investigated.

PCA is an important biologically active component of some traditional Chinese medicines. Previous studies have indicated that PCA has antioxidant activity, antibacterial activity [41], anticancer activity [42], anti-aging activity [43], and anti-inflammatory activity [44]. Furthermore, PCA is a widely distributed, naturally occurring phenolic acid and has structural similarity with caffeic acid, syringic acid and gallic acid [45]. Therefore, we speculated that these compounds had strongly similar biological functions. Polyphenols are secondary metabolites that are found ubiquitously in many higher plants and play important roles in defending against plant pathogens by suppressing microbial virulence factors, such as inhibiting biofilm formation and reducing adhesion to the host [35]. Lee et al. reported that tea catechins showed a significant antipathogenic effect against Escherichia coli O157:H7 by suppressing biofilm formation and swarming motility [46]. Those results were consistent with the results of this study in which PCA inhibited biofilm formation and the swarming ability of R. solanacearum (Figures 5-7).

PCA, caffeic acid and gallic acid are all polyphenols that have potential antibacterial activity for food and plant diseases. Moreover, these compounds all have a similar chemical structure, consisting of a benzene ring with two or three hydroxyl groups. Their structural similarity and diversity may be involved in determining their anti-tumor, anti-bacterial, and anti-proliferative bioactivity. Farag et al. demonstrated that gallic acid extracted from Acacia arabica and Punica granatum displayed significant antimicrobial activity against $R$. solanacearum (MIC values $0.5-9 \mathrm{mg} / \mathrm{mL}$ ) [47]. Methyl gallate also showed a strong inhibitory effect on $R$. solanacearum at an $\mathrm{IC}_{50} \mathrm{of} 8.3 \mathrm{mg} / \mathrm{L}$ and MIC of $20 \mathrm{mg} / \mathrm{L}$. 
A disease control trial in planta indicated that methyl gallate could effectively control tomato bacterial wilt [20]. In addition, gallic acid possessed a high antifungal activity against Fusarium solani via the degradation of fungal cell walls [48]. In addition, Zhao et al. demonstrated that flavonoids isolated from the Chinese medicinal plant Dalbergia odorifera exhibited a stronger inhibitory activity against R. solanacearum [16]. In this study, our findings indicated that PCA exhibited a strong inhibitory effect on the growth of $R$. solanacearum in vitro (Figures 1 and 2), and also could control tobacco bacterial wilt effectively in planta (Figure 9).

The MIC of an antibacterial agent is the lowest concentration required to simply inhibit the growth of bacteria. The $\mathrm{MBC}$ is the minimal concentration of an agent that kills a particular bacterium. An antibacterial agent is usually regarded as bacterial if the MBC is not more than four times the MIC [49]. The result reported in this study showed that the MBC $(40 \mu \mathrm{g} / \mathrm{mL})$ was two times the MIC $(20 \mu \mathrm{g} / \mathrm{mL})$ for PCA, which means it does meet this general rule of thumb to be labeled as an antibiotic. However, it should also be noted that some antibiotics caused an aggregation effect of bacterial cells which could have large impacts on the MIC and MBC calculations. Previous studies showed that some flavonoids induce bacterial aggregation [50]. Then further findings demonstrated that the flavonol galangin caused Staphylococcus aureus cells to clump together, and this aggregation effect led to the decreases in bacterial numbers detected in the time-kill assay and the MBC was determined [51]. The decreases in MBC assays may have been caused by bacterial aggregation rather than cell death. In this report, the calculated MIC and MBC of PCA were measured by using the agar dilution technique. The time-kill assay conducted in the present study indicated that $40 \mu \mathrm{g} / \mathrm{mL}$ of PCA could strongly inhibit the growth of the bacteria, and this result was consistent with that measured by the agar dilution assay. Therefore, it could be speculated that PCA could not cause the aggregation of R. solanacearum cells.

In this report, we have shown that PCA could significantly decrease the incidence of tobacco bacterial wilt at concentrations greater than $40 \mu \mathrm{g} / \mathrm{mL}$ in a greenhouse experiment. Although PCA has shown potential as an effective bactericide for the control of bacterial wilt, it is not known whether the control efficiency can be sustained during the tobacco growth cycle in the field. Further research is required to analyze the Ralstonia populations' dynamics, and to explore the optimal application and duration of protection. In addition, a new form of plant-type antibiotic or a new antibacterial drug could be developed via minor modifications based on the structure of PCA. New studies for the further verification of the antibacterial mechanism of PCA against $R$. solanacearum at the physiological and molecular levels need to be performed. These studies would provide a scientific and theoretical basis for developing novel compounds and improving their antibacterial effects.

\section{Materials and Methods}

\subsection{Chemicals and Bacterial Strains}

PCA (HPLC $\geqslant 98 \%$ ) used in this study was purchased from the Shanghai Yuanye Bio-Technology Co., Ltd. (Shanghai, China). PCA was dispersed in 20\% dimethyl sulfoxide (DMSO) at a concentration of $20 \mathrm{mg} / \mathrm{mL}$ and diluted in sterile distilled water $\left(\mathrm{ddH}_{2} \mathrm{O}\right)$ to the desired concentration. R. solanacearum (phylotype I, race1, biovar 3) was used throughout the study [52].

\subsection{Determination of the $M I C$ and the $M B C$}

The minimum inhibitory concentration (MIC) and the minimum bactericidal concentration (MBC) of PCA was calculated by agar dilution assay at different concentrations $(10,20,30,40 \mu \mathrm{g} / \mathrm{mL}) \mathrm{in}$ petri dishes. One hundred microliters of a $R$. solanacearum suspension adjusted to $1 \times 10^{5} \mathrm{cfu} / \mathrm{mL}$ was spread directly onto each antibiotic-containing agar dilution plate. Plates with $1 \%$ DMSO but without PCA and without any additives were used as controls. The plates were incubated at $30 \pm 1^{\circ} \mathrm{C}$. The MIC was determined as the lowest concentration at which no colony formation was observed after 
cultured $48 \mathrm{~h}$. The MBC was defined as the lowest concentration of PCA that prevented the growth of bacteria after cultured $96 \mathrm{~h}$. All assays were independently repeated at least three times.

\subsection{Antimicrobial Assay}

The antimicrobial activity of PCA was evaluated by examining the OD growth curves as follows. PCA dissolved in DMSO was added into $100 \mathrm{~mL}$ of beer extract broth obtain a final concentrations of $10,20,30$ or $40 \mu \mathrm{g} / \mathrm{mL}$, and the control culture was supplemented with $1 \%$ DMSO alone. The medium was inoculated with $100 \mu \mathrm{L}$ of a freshly cultured suspension of $R$. solanacearum $\left(1 \times 10^{9} \mathrm{cfu} / \mathrm{mL}\right)$. The cultures were incubated at $180 \mathrm{r} / \mathrm{min}$ for $36 \mathrm{~h}$ at $30{ }^{\circ} \mathrm{C}$, and cell growth was monitored spectrophotometrically (the optical density at $600 \mathrm{~nm}$ was recorded at $2 \mathrm{~h}$ intervals). All treatments were determined in triplicated and calculated to obtain an average value.

\subsection{Bacterial Morphology}

The morphology of $R$. solanacearum cells in the presence of PCA was evaluated using a scanning electron microscope. $R$. solanacearum at the logarithmic growth phase was diluted into a $10^{8} \mathrm{cfu} / \mathrm{mL}$ suspension of beer extract broth. PCA was added to the bacterial suspension to reach a final concentration of $30 \mu \mathrm{g} / \mathrm{mL}$ and $40 \mu \mathrm{g} / \mathrm{mL}$. The bacterial suspension was then shaken at $180 \mathrm{r} / \mathrm{min}$ and $30{ }^{\circ} \mathrm{C}$ for $12 \mathrm{~h}$. The cells were collected by centrifugation at $6000 \mathrm{rpm}$ for $5 \mathrm{~min}$, washed three times with $0.1 \mathrm{~mol} / \mathrm{L} \mathrm{pH} 7.0$ phosphate buffer, and were then fixed in a $2.5 \%$ glutaraldehyde solution at $4{ }^{\circ} \mathrm{C}$ overnight. After fixation, the cells were dehydrated in a graded ethanol series $(1 \mathrm{~mL} ; 30 \%, 50 \%, 70 \%$, $85 \%$ and $95 \%$ ) with two changes every $5 \mathrm{~min}$. The final cells were resuspended in Tert-butanol and fixed on the smooth surface of aluminum foil for observing after spraying with gold. Suspensions with $0.1 \%$ DMSO added and an untreated control were used.

\subsection{Biofilm Formation Assay}

The biofilm formation assay was performed by crystal violet staining as described by Petters et al. with slight modifications [53]. A polystyrene microtiter plate assay was used to quantify biofilm formation by $R$. solanacearum. Five centrifuge tubes were sterilized, and to each tube the $5 \mathrm{~mL}$ mixed cultures were added $\left(5 \mu \mathrm{L}\right.$ of inoculum $\left(\mathrm{OD}_{600} \approx 1.0\right)$ mixed with a final PCA concentration of $10 \mu \mathrm{g} / \mathrm{mL}, 20 \mu \mathrm{g} / \mathrm{mL}, 30 \mu \mathrm{g} / \mathrm{mL}$ and $40 \mu \mathrm{g} / \mathrm{mL}$ in beer extract broth and without PCA as a control). Biofilm growth was initiated by inoculating $200 \mu \mathrm{L}$ of mixed cultures into individual wells of a 96-well microtiter plate. The plates were sealed with plastic wrap and incubated without shaking for 12,24 and $36 \mathrm{~h}$ at $30{ }^{\circ} \mathrm{C}$. At the end of the incubation period, the liquid medium was removed and immediately washed three times with distilled water. Each well was stained with $0.1 \%$ crystal violet for $30 \mathrm{~min}$. After staining, each well was washed three times with distilled water to remove excess stain. The crystal violet was removed from the complex with $200 \mu \mathrm{L}$ of $95 \%$ ethanol, and the absorbance values of biofilms was measured on a microplate reader at $\mathrm{OD}_{490 \mathrm{~nm}}$. Each treatment had three replications, and the experiment was performed three times.

\subsection{Swarming Assay}

The swarming assay was based on Englert et al. [54] with slight modifications. A semisolid medium containing $0.35 \%$ agar [55] supplemented with PCA at various concentrations (10, 20, 30 and $40 \mu \mathrm{g} / \mathrm{mL}$ ) was prepared. Then, the petri dishes were air-dried for $30 \mathrm{~min}$ on a bacteria-free work bench. An overnight culture of $R$. solanacearum $\left(\mathrm{OD}_{600} \approx 0.8\right)$ was collected and washed twice using sterile water at $6000 \mathrm{rpm}$ for $5 \mathrm{~min}$ and resuspended in sterile water. The bacterial suspension $(2 \mu \mathrm{L})$ was drop-inoculated at the center of semisolid medium plates. The colony diameters were measured in both the vertical and the horizontal direction on each plate in triplicate after incubation for $24 \mathrm{~h}$ and $48 \mathrm{~h}$ at $28^{\circ} \mathrm{C}$. The results were expressed as the mean of three independent experiments. 


\subsection{Effect of PCA on Seedling Tobacco Incubated with R. solanacearum}

Pot experiments were conducted to appraise the effect of PCA for controlling tobacco bacterial wilt. First, $5 \mathrm{~mL}$ of a freshly culture of a $R$. solanacearum inoculum solution at $10^{7} \mathrm{cfu} / \mathrm{mL}$ was inoculated in the rhizosphere. Then, a $10 \mathrm{~mL}$ solution of PCA $(40 \mathrm{mg} / \mathrm{L})$ or streptomycin $(40 \mathrm{mg} / \mathrm{L})$ was irrigated to the tobacco roots, which were inoculated with $R$. solanacearum two days later. A mixture consisting of DMSO with water in the proper proportion was poured on the control tobacco seedlings. The seedlings were cultivated in the greenhouse at a temperature of $30 \pm 1{ }^{\circ} \mathrm{C}$ with a relative humidity of $85 \%$ to $90 \%$. The incidence of bacterial wilt was monitored every two days, from seven days to 19 days after inoculation. In this experiment, each treatment had three replicates and each replicate included 20 tobacco plants. The disease rate was quantified as $0=$ no symptoms; $1=$ a small number of wilting leaves or a side with a streak spot; 2 = a diseased side with over half wilting leaves or a stem with a black steak spot under the top of the tobacco plant; 3 = a diseased side with over two-thirds wilting leaves or a stem with a black steak spot up to the top of the tobacco plant; and $4=$ the entire plant died. To determine disease index and the control efficiency, we used the following formula:

$$
\text { Disease index }=\frac{\sum\left(n_{i} \times v_{i}\right)}{N \times 4} \times 100
$$

where $n_{i}=$ the number of plants with respective disease index, $v_{i}=$ disease index $(0,1,2,3,4)$, and $N=$ the total number of plants used in each treatment.

$$
\text { Control efficiency }(\%)=\frac{C K-T}{C K} \times 100(\%)
$$

where $T=$ the disease index of treatment, $C K=$ the disease index of control group.

\section{Conclusions}

In conclusion, this study evaluated the antibacterial activity of plant-derived protocatechualdehyde (PCA), which is the major active ingredient of $S$. miltiorrhizae against $R$. solanacearum. The results of this study indicate that the PCA had the strongest antibacterial activity and could be a potential antibacterial agent. The biological activity of PCA is largely due to its disruptive effect on the cell structure and shapes. Moreover, PCA could significantly reduce biofilm formation and suppress the swarming motility of $R$. solanacearum. Experiments conducted in the greenhouse showed that PCA also significantly reduced the incidence of bacterial wilt of tobacco. Overall, this is the first report concerning the antibacterial effects of PCA on plant-pathogenic bacteria. Further studies are expected to assess its control efficacy in the field and to explore its optimal application. Moreover, further structural modification and design based on PCA could improve the biological activity and contribute to the development of new antibacterial drugs against infections of R. solanacearum.

Acknowledgments: This work was supported by the key Projects of the China National Tobacco Corporation (110201202002).

Author Contributions: J.C. conceived and designed the experiments; Y.Y., L.Y., B.G. performed the experiments and analyzed the data; S.L. wrote the paper; D.W., J.C. revised the paper.

Conflicts of Interest: The authors declare that they have no conflict of interest.

\section{References}

1. Genin, S.; Denny, T.P. Pathogenomics of the Ralstonia solanacearum species complex. Annu. Rev. Phytopathol. 2012, 50, 67-89. [CrossRef] [PubMed]

2. Elphinstone, J.G.; Allen, C.; Prior, P.; Hayward, A.C. The current bacterial wilt situation: A global overview. In Bacterial Wilt Disease and the Ralstonia solanacearum Species Complex; American Phytopathological Society: St Paul, MN, USA, 2005; pp. 9-28. 
3. Salanoubat, M.; Genin, S.; Artiguenave, F.; Gouzy, J.; Mangenot, S.; Arlat, M.; Chandler, M. Genome sequence of the plant pathogen Ralstonia solanacearum. Nature 2002, 415, 497-502. [CrossRef] [PubMed]

4. Li, L.; Feng, X.; Tang, M.; Hao, W.; Han, Y.; Zhang, G.; Wan, S. Antibacterial activity of Lansiumamide B to tobacco bacterial wilt (Ralstonia solanacearum). Microbiol. Res. 2014, 169, 522-526. [CrossRef] [PubMed]

5. Hayward, A.C. Biology and epidemiology of bacterial wilt caused by Pseudomonas solanacearum. Annu. Rev. Phytopathol. 1991, 29, 65-87. [CrossRef] [PubMed]

6. Denny, T.P.; Brumbley, S.M.; Carney, B.F.; Clough, S.J.; Schell, M.A.; Hayward, A.C.; Hartman, G.L. Phenotype conversion of Pseudomonas solanacearum: Its molecular basis and potential function. In Bacterial Wilt: The Disease and Its Causative Agent, Pseudomonas solanacearum; CABI: Wallingford, UK, 1994; pp. 137-155.

7. Meng, F. The Virulence Factors of the Bacterial Wilt Pathogen Ralstonia solanacearum. J. Plant Pathol. Microb. 2013, 4, 2. [CrossRef]

8. Coll, N.S.; Valls, M. Current knowledge on the Ralstonia solanacearum type III secretion system. Microb. Biotechnol. 2013, 6, 614-620. [PubMed]

9. Kao, C.C.; Barlow, E.; Sequeira, L. Extracellular polysaccharide is required for wild-type virulence of Pseudomonas solanacearum. J. Bacteriol. 1992, 174, 1068-1071. [PubMed]

10. Poueymiro, M.; Genin, S. Secreted proteins from Ralstonia solanacearum: A hundred tricks to kill a plant. Curr. Opin. Microbiol. 2009, 12, 44-52. [CrossRef] [PubMed]

11. Tans-Kersten, J.; Huang, H.; Allen, C. Ralstonia solanacearum needs motility for invasive virulence on tomato. J. Bacteriol. 2001, 183, 3597-3605. [CrossRef] [PubMed]

12. Genin, S.; Boucher, C. Lessons learned from the genome analysis of Ralstonia solanacearum. Annu. Rev. Phytopathol. 2004, 42, 107-134. [CrossRef] [PubMed]

13. Wang, X.; Liu, X.; Han, H. Evaluation of antibacterial effects of carbon nanomaterials against copper-resistant Ralstonia solanacearum. Colloids Surf. B Biointerfaces 2013, 103, 136-142. [CrossRef] [PubMed]

14. Hosseinzadeh, S.; Shams-Bakhsh, M.; Hosseinzadeh, E. Effects of sub-bactericidal concentration of plant essential oils on pathogenicity factors of Ralstonia solanacearum. Arch. Phytopathol. Plant Prot. 2013, 46, 643-655. [CrossRef]

15. Yi, Y.; Liu, R.; Yin, H.; Luo, K. Isolation, identification and field control efficacy of endophytic strain against tobacco bacterial wilt. Chin. J. Appl. Ecol. 2007, 18, 554-558.

16. Zhao, X.; Mei, W.; Gong, M.; Zuo, W.; Bai, H.; Dai, H. Antibacterial activity of the flavonoids from Dalbergia odorifera on Ralstonia solanacearum. Molecules 2011, 16, 9775-9782. [CrossRef] [PubMed]

17. Ji, P.; Momol, M.T.; Olson, S.M.; Pradhanang, P.M.; Jones, J.B. Evaluation of thymol as biofumigant for control of bacterial wilt of tomato under field conditions. Plant Dis. 2005, 89, 497-500. [CrossRef]

18. Hong, J.C.; Momol, M.T.; Ji, P.; Olson, S.M.; Colee, J.; Jones, J.B. Management of bacterial wilt in tomatoes with thymol and acibenzolar-S-methyl. Crop Prot. 2011, 30, 1340-1345. [CrossRef]

19. Kim, J.Y.; Park, S.C.; Hwang, I.; Cheong, H.; Nah, J.W.; Hahm, K.S.; Park, Y. Protease inhibitors from plants with antimicrobial activity. Int. J. Mol. Sci. 2009, 10, 2860-2872. [CrossRef] [PubMed]

20. Yuan, G.Q.; Li, Q.Q.; Qin, J.; Ye, Y.F.; Lin, W. Isolation of methyl gallate from Toxicodendron sylvestre and its effect on tomato bacterial wilt. Plant Dis. 2012, 96, 1143-1147. [CrossRef]

21. Yuan, G.; Li, Q.; Wang, J.; Zeng, D.; Wu, D.; Yang, L.; Qin, J.; Cao, Z.; Li, H. Screening of plants for antimicrobial activity to phytopathogenic bacteria. Plant Prot. 2010, 4, 052.

22. Fan, W.W.; Yuan, G.Q.; Li, Q.Q.; Lin, W. Antibacterial mechanisms of methyl gallate against Ralstonia solanacearum. Australas. Plant Pathol. 2014, 43, 1-7. [CrossRef]

23. Paret, M.L.; Cabos, R.; Kratky, B.A.; Alvarez, A.M. Effect of plant essential oils on Ralstonia solanacearum race 4 and bacterial wilt of edible ginger. Plant Dis. 2010, 94, 521-527. [CrossRef]

24. Pradhanang, P.M.; Momol, M.T.; Olson, S.M.; Jones, J.B. Effects of plant essential oils on Ralstonia solanacearum population density and bacterial wilt incidence in tomato. Plant Dis. 2003, 87, 423-427. [CrossRef]

25. Paret, M.L.; Sharma, S.K.; Alvarez, A.M. Characterization of biofumigated Ralstonia solanacearum cells using micro-Raman spectroscopy and electron microscopy. Phytopathology 2012, 102, 105-113. [CrossRef] [PubMed]

26. Feng, C.T.; Su, H.J.; Chen, C.T.; Ho, W.C.; Tsou, Y.R.; Chern, L.L. Inhibitory Effects of Chinese Medicinal Herbs on Plant-Pathogenic Bacteria and Identification of the Active Components from Gallnuts of Chinese Sumac. Plant Dis. 2012, 96, 1193-1197. [CrossRef]

27. Deberdt, P.; Perrin, B.; Coranson-Beaudu, R.; Duyck, P.F.; Wicker, E. Effect of Allium fistulosum extract on Ralstonia solanacearum populations and tomato bacterial wilt. Plant Dis. 2012, 96, 687-692. [CrossRef] 
28. Cho, J.Y.; Choi, G.J.; Son, S.W.; Jang, K.S.; Lim, H.K.; Lee, S.O.; Kim, J.C. Isolation and antifungal activity of lignans from Myristica fragrans against various plant pathogenic fung. Pest Manag. Sci. 2007, 63, 935-940. [CrossRef] [PubMed]

29. Choi, J.; Jiang, X.; Jeong, J.B.; Lee, S.H. Anticancer activity of protocatechualdehyde in human breast cancer cells. J. Med. Food 2014, 17, 842-848. [CrossRef] [PubMed]

30. Shen, L.H.; Wang, B.Y.; Wang, C.Q.; Xie, X.L.; Yu, G.R.; Yao, Z.Y.; Yang, B.J. Effect of danshensu, protocatechualdehyde and danshen injection on calcium ion concentration in cytoplasm of human erythrocytes. China J. Chin. Mater. Med. 2004, 29, 984-988.

31. Prachayasittikul, S.; Buraparuangsang, P.; Worachartcheewan, A.; Isarankura-Na-Ayudhya, C.; Ruchirawat, S.; Prachayasittikul, V. Antimicrobial and antioxidative activities of bioactive constituents from Hydnophytum formicarum Jack. Molecules 2008, 13, 904-921. [CrossRef] [PubMed]

32. Becker, J.O.; Schwinn, F.J. Control of soil-borne pathogens with living bacteria and fungi: Status and outlook. Pestic. Sci. 1993, 37, 355-363. [CrossRef]

33. Dixon, R.A. Natural products and plant disease resistance. Nature 2001, 411, 843-847. [CrossRef] [PubMed]

34. Cushnie, T.P.T.; Lamb, A.J. Antimicrobial activity of flavonoids. Int. J. Antimicrob. Agents 2005, 26, 343-356. [CrossRef] [PubMed]

35. Daglia, M. Polyphenols as antimicrobial agents. Curr. Opin. Biotechnol. 2012, 23, 174-181. [CrossRef] [PubMed]

36. Popova, M.P.; Chinou, I.B.; Marekov, I.N.; Bankova, V.S. Terpenes with antimicrobial activity from Cretan propolis. Phytochemistry 2009, 70, 1262-1271. [CrossRef] [PubMed]

37. Sansores-Peraza, P.; Rosado-Vallado, M.; Brito-Loeza, W.; Mena-Rejon, G.J.; Quijano, L. Cassine, an antimicrobial alkaloid from Sennaracemosa. Fitoterapia 2000, 71, 690-692. [CrossRef]

38. Yang, L.; Ding, W.; Xu, Y.; Wu, D.; Li, S.; Chen, J.; Guo, B. New Insights into the Antibacterial Activity of Hydroxycoumarins against Ralstonia solanacearum. Molecules 2016, 21, 468. [CrossRef] [PubMed]

39. Jeong, J.B.; Lee, S.H. Protocatechualdehyde possesses anti-cancer activity through downregulating cyclin D1 and HDAC2 in human colorectal cancer cells. Biochem. Biophys. Res. Commun. 2013, 430, 381-386. [CrossRef] [PubMed]

40. Lee, S.; Shim, S.H.; Kim, J.S.; Shin, K.H.; Kang, S.S. Aldose reductase inhibitors from the fruiting bodies of Ganoderma applanatum. Biol. Pharm. Bull. 2005, 28, 1103-1105. [CrossRef] [PubMed]

41. Chao, C.Y.; Yin, M.C. Antibacterial effects of roselle calyx extracts and protocatechuic acid in ground beef and apple juice. Foodborne Pathog. Dis. 2009, 6, 201-206. [CrossRef] [PubMed]

42. Hudson, E.A.; Dinh, P.A.; Kokubun, T.; Simmonds, M.S.; Gescher, A. Characterization of potentially chemopreventive phenols in extracts of brown rice that inhibit the growth of human breast and colon cancer cells. Cancer Epidemiol. Biomark. Prev. 2000, 9, 1163-1170.

43. Guan, S.; Bao, Y.M.; Jiang, B.; An, L.J. Protective effect of protocatechuic acid from Alpinia oxyphylla on hydrogen peroxide-induced oxidative PC12 cell death. Eur. J. Pharmacol. 2006, 538, 73-79. [CrossRef] [PubMed]

44. Liu, C.L.; Wang, J.M.; Chu, C.Y.; Cheng, M.T.; Tseng, T.H. In vivo protective effect of protocatechuic acid on tert-butyl hydroperoxide-induced rat hepatotoxicity. Food Chem. Toxicol. 2002, 40, 635-641. [CrossRef]

45. Kakkar, S.; Bais, S. A review on protocatechuic acid and its pharmacological potential. ISRN Pharmacol. 2014. [CrossRef] [PubMed]

46. Lee, K.M.; Kim, W.S.; Lim, J.; Nam, S.Y.; Youn, M.; Nam, S.W.; Kim, Y.h.; Kim, S.H.; Park, W.J.; Park, S.S. Antipathogenic properties of green tea polyphenol epigallocatechin gallate at concentrations below the MIC against enterohemorrhagic Escherichia coli O157:H7. J. Food Prot. 2009, 72, 325-331. [PubMed]

47. Farag, M.A.; Al-Mahdy, D.A.; Salah El Dine, R.; Fahmy, S.; Yassin, A.; Porzel, A.; Brandt, W. Structure Activity Relationships of Antimicrobial Gallic Acid Derivatives from Pomegranate and Acacia Fruit Extracts against Potato Bacterial Wilt Pathogen. Chem. Biodivers. 2015, 12, 955-962. [CrossRef] [PubMed]

48. Seo, D.J.; Lee, H.B.; Kim, I.S.; Kim, K.Y.; Park, R.D.; Jung, W.J. Antifungal activity of gallic acid purified from Terminalia nigrovenulosa bark against Fusarium solani. Microb. Pathogen. 2013, 56, 8-15.

49. French, G.L. Bactericidal agents in the treatment of MRSA infections-The potential role of daptomycin. J. Antimicrob. Chemother. 2006, 58, 1107-1117. [CrossRef] [PubMed]

50. Ikigai, H.; Nakae, T.; Hara, Y.; Shimamura, T. Bactericidal catechins damage the lipid bilayer. Biochim. Biophys. Acta (BBA) Biomembr. 1993, 1147, 132-136. [CrossRef] 
51. Cushnie, T.P.; Hamilton, V.E.; Chapman, D.G.; Taylor, P.W.; Lamb, A.J. Aggregation of Staphylococcus aureus following treatment with the antibacterial flavonol galangin. J. Appl. Microbiol. 2007, 103, 1562-1567. [CrossRef] [PubMed]

52. Wu, D.; Ding, W.; Zhang, Y.; Liu, X.; Yang, L. Oleanolic acid induces the type III secretion system of Ralstonia solanacearum. Front. Microbiol. 2015, 6, 1466. [CrossRef] [PubMed]

53. Peeters, E.; Nelis, H.J.; Coenye, T. Comparison of multiple methods for quantification of microbial biofilms grown in microtiter plates. J. Microbiol. Methods 2008, 72, 157-165. [CrossRef] [PubMed]

54. Englert, D.L.; Jayaraman, A.; Manson, M.D. Microfluidic techniques for the analysis of bacterial chemotaxis. Chemotaxis 2009, 571, 1-23.

55. Kelman, A.; Hruschka, J. The role of motility and aerotaxis in the selective increase of avirulent bacteria in still broth cultures of Pseudomonas solanacearum. Microbiology 1973, 76, 177-188. [CrossRef] [PubMed]

Sample Availability: Sample of the compound protocatechualdehyde is available from the authors.

(C) 2016 by the authors; licensee MDPI, Basel, Switzerland. This article is an open access article distributed under the terms and conditions of the Creative Commons Attribution (CC-BY) license (http://creativecommons.org/licenses/by/4.0/). 